\title{
Socio-ecological transitions toward low-carbon port cities: trends, changes and adaptation processes in Asia and Europe
}

\author{
Nicolas Mat ${ }^{\text {a, * }}$, Juliette Cerceau ${ }^{\text {a }}$, Lei Shi ${ }^{\text {b }}$, Hung-Suck Park ${ }^{c}$, Guillaume Junqua ${ }^{\text {a }}$, \\ Miguel Lopez-Ferber ${ }^{\mathrm{a}}$

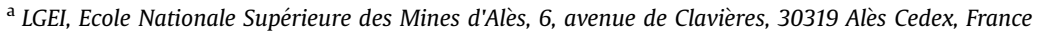 \\ ${ }^{\mathrm{b}}$ State Environmental Protection Key Laboratory of Eco-industry, School of Environment, Tsinghua University, Beijing 100084, China \\ ${ }^{c}$ Center for Clean Technology and Resource Recycling (689-749) 35-404, University of Ulsan, Daehakro 93, Nam-Gu, Ulsan, South Korea
}

\section{A B S T R A C T}

Industrial port cities are essential components in a society dependant on fossil fuels and low cost energy. In the global move towards a low-carbon society, industrial port cities are emblematic of complex and integrated socio-ecological systems, which are experiencing transition processes related to interactions between bio-geo-physical components and governance. Using a socio-ecological system framework, this article provides insights into innovative regional eco-industrial development strategies for moving toward a low-carbon future in industrial port areas. Based on three case studies (Marseille-Fos in France, Ningbo in China, and Ulsan in South Korea), our analysis focuses on the changing relationships between energy, land cover, time use, and governance. The historical socio-ecological transition of industrial port cities is described as a stepwise process of spatial and functional disconnection/connection of port industrial complexes, which decouple/combine the port city's metabolism from local resources. We highlight the impacts of globalization on port-city socio-ecological trends, describing the effects of the integration of port cities into global economic processes, the impact of global awareness on global environmental changes, and the accelerating pace of change. We compare low-carbon strategies, revealing similarities in terms of conversion toward low carbon sources and growing connectedness and functional diversity of port-industrial systems.

Keywords:

Industrial ecology

Industrial symbiosis

Energy

Port-city interface

Socio-ecological transition

Asia-Europe comparison

\section{Introduction}

More than $50 \%$ of the world's population now lives in urban areas. Around the world, urban areas are expanding on average twice as fast than their populations (Seto et al., 2012). Cities, as concentrated centers of production, consumption and waste disposal thus drive major global environmental challenges such as biogeochemical cycles, climate, biodiversity (Grimm et al., 2008). They drive planetary processes overriding the biosphere's established balances, cycles and feedbacks (Chen et al., 2014). In particular, urban areas are responsible of $80 \%$ of humanity's greenhouse gas (Feng et al., 2013). Therefore, cities play a crucial role in determining the socioecological trajectories of nations, and, in particular, their energy and carbon emissions profiles and trends. In $2010,65 \%$ of cities with populations above 1.3 million were

\footnotetext{
* Corresponding author. Tel.: +33 (0)466785314; fax: +33 (0)466782701.

E-mail address: nicolas.mat.conseil@gmail.com (N. Mat).
}

located along the world coasts (Vallega, 2001). In 2030, urban population growth will be concentrated in a few regions, including long coastal urban corridors (Seto et al., 2012). The disproportionate location of cities along rivers and coastlines make these areas major contributors to low carbon strategies. Coastal areas, and especially port cities, concentrate factors that have been proved to have a direct influence on $\mathrm{CO}_{2}$ emissions. Through their literature review, Wang et al. $(2012 \mathrm{a}, \mathrm{b})$ pointed out that $\mathrm{CO}_{2}$ emissions were positively related to economic growth, demographic growth, urbanization, industrialization and trade liberalization. In port cities, the conflict between emission reduction targets and economic growth appears inevitable and may affect port-industrial competitiveness and resilience. Moreover, port cities are at the core of energy transition issues. A significant proportion of maritime exchanges concern fossil energy products. In 2011, 2.820 million tons of crude oil and oil products were transported on globally established maritime routes, accounting for nearly $32 \%$ of global maritime traffic. In 2010, global Liquid Natural Gas (LNG) shipping increased by $22 \%$ to reach 297.6 billion $\mathrm{Nm}^{3}$. There were ninety LNG 
terminals in 20 countries, while China was planning to build 6 new LNG terminals. In response to the growing demand of developing countries, coal exportations increased by than $14 \%$ in 2010 , to 904 million tons, or $10 \%$ of global traffic (UNCTAD, 2011). On the other hand, the scarcity of fossil fuel resources questions port-city adaptability and vulnerability in the long term. Driven both by forecasts for increasing oil prices that may diminish imports in the future, and by the increasing stringency of national environmental regulations and energy independency strategies, many ports have to consider new energy strategies (Merk, 2011). These strategies herald a revolution in the main function of ports, from the importation of foreign energy sources (coal and oil) to the production of local low carbon energy including off- and on-shore power and renewable energy generation.

Among the low-carbon strategies, this article focuses on the innovative regional eco-industrial development policies implemented in port city areas. Industrial ecology (IE) seeks to optimize resource management by intensifying interactions between different stakeholders occupying a common geographic area. Industrial symbiosis (IS) has been defined as engaging traditionally separate activities in physical exchanges of materials and energy (Chertow, 2000). IS presupposes better coordination between economic actors (Boons and Baas, 1997). Going beyond the technological changes in processes and products, IE articulates technological and organizational innovations (OECD, 2009). Cerceau et al. (2014) provide an international survey that describes the different port-city strategies adopted to implement IE, from portbased IE complexes to inter-port IE networks. The purpose of these low carbon strategies is not to evolve toward energy selfreliant nor net energy producing areas. The objective is to keep creating value by generating fewer greenhouse gas emissions and by consuming less energy through technological development and optimization of the management of consumption and production processes. The increasing use of local and renewable energy is also considered as a lever, although it supposes that the operating conditions of the intermittent type of energy sources should be adjusted to meet out the future demands.

The factors which contribute to the socio-ecological transitions for moving towards a low-carbon future are better understood today. Among the recurring factors that can explain or foster the global move toward a post carbon transition, the Intergovernmental Panel on Climate Change consider the rising energy prices, the increasing environmental awareness leading to a change in pollution and emission standards, the will to secure supplies and reduce dependence on imported fossil fuels, the concrete effects of climate change on agricultural yields, the rising sea levels as well as the technological development (IPCC, 2014). They are also common factors that apply to port industrial areas, although no specific baseline factor really stands up. The major difference concerning these port industrial areas is not so much of qualitative nature (the energy mix is not so different than that consumed in other industrial areas) but of quantitative nature (consumption levels and energy dissipation are much higher than in other industrial areas).

Port cities thus appear as microcosms of low carbon challenges and offer opportunities to highlight different low carbon development patterns. This article analyzes the current changes and adaptation processes toward a low-carbon future in port cities in Asia and Europe, focusing on three in-depth case studies: Marseille in France, Ningbo in China, and Ulsan in South Korea. It has become evident that urban development problems require a multidisciplinary approach to enhance the understanding of the role of urban areas in global environmental change. Urban ecosystem modeling (UEM) integrates the theory and methods of natural, engineering and social sciences, considering the city as a whole system emerging through the socio-techno-ecological components and interactions they encapsulate (Chen et al., 2014). Embedding in the UEM conceptual framework, we consider port cities as complex, dynamic and adaptive socioecological systems. Alike other ecosystems, port cities have their own structures, processes and functions. We employ the concepts of socio-ecological regimes and transitions to identify and analyze the changes and adaptation processes in these European and Asian port cities. The socioecological system (SES) framework focuses on complex and integrated systems that emerge through the continuous interactions of human societies with ecosystems (Redman et al., 2004; Haberl et al., 2006). For instance, the spatial patterns of urban and industrial expansion - and associated land cover and land use - affects carbon storage, energy use and carbon emissions (Seto et al., 2012). It regards these socio-ecological interactions as a dynamic process in which self-organized sub-systems interact. Resource systems and units, users, and governance systems are relatively separate, but interact to produce outcomes at the complex SES level (Ostrom, 2009). The evolution of human societies can be understood as the succession of different socio-ecological regimes that establish distinct patterns of society-biosphere interactions (Krausmann et al., 2008; Schandl et al., 2009). Technological change, economic developments, political revolutions, and resource scarcity at the global scale have a decisive impact on socioecological interactions in specific regions (Haber et al., 2006). Krausmann and Fisher-Kowalski (2013) provide a macroperspective on the evolution of society-interactions during industrialization, highlighting the links between global energy metabolism, technological changes, economic and demographic developments, and environmental issues.

Following Young et al. (2006), we propose to consider the effects of globalization on the resilience, vulnerability, and adaptability of port city systems. Globalization can be defined as a process "that encompasses the causes, course and consequences of transnational and transcultural integration of human and non-human activities" (Nayef et al., 2006). It refers to the worldwide integration and compression of temporal and spatial dimensions of human-nature interactions. Port industrial areas are deeply embedded in the globalized system. For Hoffmann and Kumar (2010), transport is one of the cornerstones of globalization, as the increased efficiency of port and shipping services has made it easier to buy and sell products at an international scale. Globalization of port activities does not only affect the port industrial complex, it also has impacts on the port region. In fact, the evolution of port cities can be explained in terms of interrelations between global and local trends. Ducruet (2009) shows that the regional environment in which ports operate is of great importance. He argues that ports cannot be considered as isolated entities connected to a global virtual network. They are part of a regional socio-economic context, and the way this context evolves strongly affects the performance of a port. Jung (2011) reviews major literature regarding port-city interfaces and highlights two distinct views about the relationship between logistic activities of ports and local economic growth. The more classical view emphasizes the pull effect of ports on the economy. An alternative view considers local development to be a generator of port development. This debate highlights the existence of synergistic relationships between ports and their local regions.

We aim to identify and analyze the changes in the socioecological regimes of port cities as well as the exogenous and endogenous processes that foster the emergence of new opportunities that lead to transitions from one regime to another. We conceptualize the historical socio-ecological transition of industrial port cities as a stepwise dynamics of spatial and functional connection/disconnection of a port-city's metabolism with/from local resources. For each case study, we investigate the changes in 
energy metabolism, land use, time use, and local governance, and highlight how global traffic trends affect local socio-ecological regimes. We provide insights into the long-term dynamics of port city socio-ecological trends, and discuss the different timeframes, portcity interfaces, and post-carbon strategies, focusing on innovative regional eco-industrial development policies approaches observed in Europe and Asia. We question the capacity of these IE strategies to reduce vulnerability thanks to adaptability and innovation.

\section{Identification of socio-ecological regimes and transitions: methodological framework}

\subsection{Case studies in Europe and Asia}

In order to analyze processes that change over the medium and long term, socio-ecological approaches encourage the comparison of results among different sites (Redman et al., 2004). Such a comparison needs case studies that can be compared (i.e. that have some similarities) and can highlight different trends and trajectories (i.e. that also have relevant differences). This article compares socio-ecological trajectories of three case studies in Europe and Asia: the Aix-Marseille-Provence metropolitan area in France, the Ulsan metropolitan area in South Korea, and the Ningbo District in China.

These three case studies have in common the following characteristics (Table 1 ):

- Scale of analysis: since administrative boundaries are very different in Europe and Asia, it was difficult to identify comparable scales of analysis. Focus on the inter-municipal cooperation level appeared to be a common denominator: intermunicipal cooperation occurs at the metropolitan scale in AixMarseille-Provence and Ulsan, combining different industrial, urban and rural municipalities. Similarly, in China, the district of Ningbo brings together urban areas such as Beilun, Zhenhai, and Yinzhou, and county areas such as Cixi and Xiangshan.

- Diversity of land use: land use and cover change have been identified as one of the prime determinants of global changes (Foley et al., 2005). To observe the trends in land use change, the study area has to include different types of land use (Ohl et al., 2007). Case studies include within their perimeter: 1/port industrial areas, 2/urban areas and 3/agricultural areas (Fig. 1).

- Energy input and production: in each case study, energy represents a major flow of the local metabolism, both in terms of inputs linked to the port traffic and in terms of production linked to energy transformation and the industrial production system. In each of these case studies, economic activity is structured around harbor-based industries (petrochemical industries, paper making, steel industry, electronic \& IT industries, energy industry), logistics and container shipping, and other traditional industries such as textile and plastics, cars factories, and shipbuilding. Among them, petrochemical industries, steel industry, energy industry are energy-intensive industries characterized by a relatively high consumption of primary and secondary energy in their production process (Wang et al., 2015)

- Low carbon strategies: each of these case studies is experimenting with initiatives turned toward a low-carbon transition, including IE approaches. Aix-Marseille-Provence Métropole launched an energy transition project aiming to increase energy efficiency, stimulate innovation and synergies at a metropolitan scale. Ulsan Metropolitan City defined a strategy for low carbon green growth through two major objectives: 1/greenhouse gas reduction and low carbon city; 2/global stronghold for green industry. In 2013, Ningbo launched a project for strengthening the capacity of low-carbon development and energy efficiency, focusing on small and middle size companies.

These case studies also have major differences that allow to highlight different trends and trajectories toward low carbon strategies: in terms of economic development, Aix Marseille Provence Metropole is located in an old industrialized European country, characterized by a long history of industrialization and globalization and an advanced and high-income, albeit stagnating, economy; Ningbo, in a new industrialized country, characterized by a real economic takeoff; Ulsan, located in one of the four Asian dragons, reaching an advanced economy after a rapid industrialization and high growth. Demographic trends and forecasts are also quite different: although urban population growth is a global phenomenon, half of the increase is forecasted to occur in Asia, and especially on Chinese coastal areas (Seto et al., 2012). Beyond the differences in terms of economic and demographic levels, the main differences concern the time scale of these evolutions.

\subsection{Identification of socio-ecological regimes and transitions}

In order to gain a socio-ecological understanding of port change and adaptation processes, we focus on specific activities that mediate between societies and ecosystems. Inspired by the model proposed by Redman et al. (2004), we conceptualize socioecological patterns and processes in port industrial regions as a stepwise change in interactions between coastal ecosystems and port cities that is expressed locally through changing relations of energy metabolism, land use, time use, and local governance (Fig. 2). Each socio-ecological regime is described on the basis of a specific characterization and articulation of these 4 variables. In terms of UEM, we endorse a hybrid approach, combining top-down models concern with economic and biophysical processes (energy flows, activity sectors) and bottom-up models focusing on land use (Chen et al., 2014).

Energy appears to be a determining dimension of socioecological interactions. For Krausmann and Fisher-Kowalski (2013), the availability of energy plays a crucial role as it defines the limits on the capacity of human societies to extract, transport, and transform resources. Specific attention is thus paid to primary

Table 1

Case studies considered in Europe and Asia.

\begin{tabular}{|c|c|c|c|c|c|c|}
\hline Case studies & Scale of analysis & $\begin{array}{l}\text { Port industrial } \\
\text { area }\end{array}$ & $\begin{array}{l}\text { Urban } \\
\text { area }\end{array}$ & $\begin{array}{l}\text { Agricultural } \\
\text { areas }\end{array}$ & Energy input and production & $\begin{array}{l}\text { Current innovative regional } \\
\text { eco-industrial development } \\
\text { policies }\end{array}$ \\
\hline $\begin{array}{l}\text { Aix Marseille Provence } \\
\text { metropolitan area (France) }\end{array}$ & $\begin{array}{l}1.833 \mathrm{M} \text { Inhabitants } \\
3173 \mathrm{~km}^{2}\end{array}$ & $104 \mathrm{~km}^{2}$ & $396 \mathrm{~km}^{2}$ & $936 \mathrm{~km}^{2}$ & $\begin{array}{l}\text { Input: } 6.55 \mathrm{MWh} / \text { year/capita } \\
\text { Production: } 2.18 \mathrm{MWh} / \text { year/capita }\end{array}$ & $\begin{array}{l}\text { Innovative strategy for the } \\
\text { energy transition }\end{array}$ \\
\hline Ningbo district (China) & $\begin{array}{l}5.777 \mathrm{M} \text { Inhabitants } \\
9816 \mathrm{~km}^{2}\end{array}$ & $172 \mathrm{~km}^{2}$ & $170 \mathrm{~km}^{2}$ & $3185 \mathrm{~km}^{2}$ & $\begin{array}{l}\text { Input: } 8.85 \mathrm{MWh} / \text { year/capita } \\
\text { Production: } 2.3 \mathrm{MWh} / \text { year/capita }\end{array}$ & $\begin{array}{l}\text { Ningbo circular economy pilot } \\
\text { city and eco-industrial park }\end{array}$ \\
\hline $\begin{array}{l}\text { Ulsan metropolitan } \\
\text { area(South Korea) }\end{array}$ & $\begin{array}{l}1.2 \mathrm{M} \text { Inhabitants } \\
1060 \mathrm{~km}^{2}\end{array}$ & $64 \mathrm{~km}^{2}$ & $50 \mathrm{~km}^{2}$ & $114 \mathrm{~km}^{2}$ & Input: $24.47 \mathrm{MWh} /$ year/capita & $\begin{array}{l}\text { Ulsan eco-polis and Ulsan } \\
\text { eco-industrial park }\end{array}$ \\
\hline
\end{tabular}




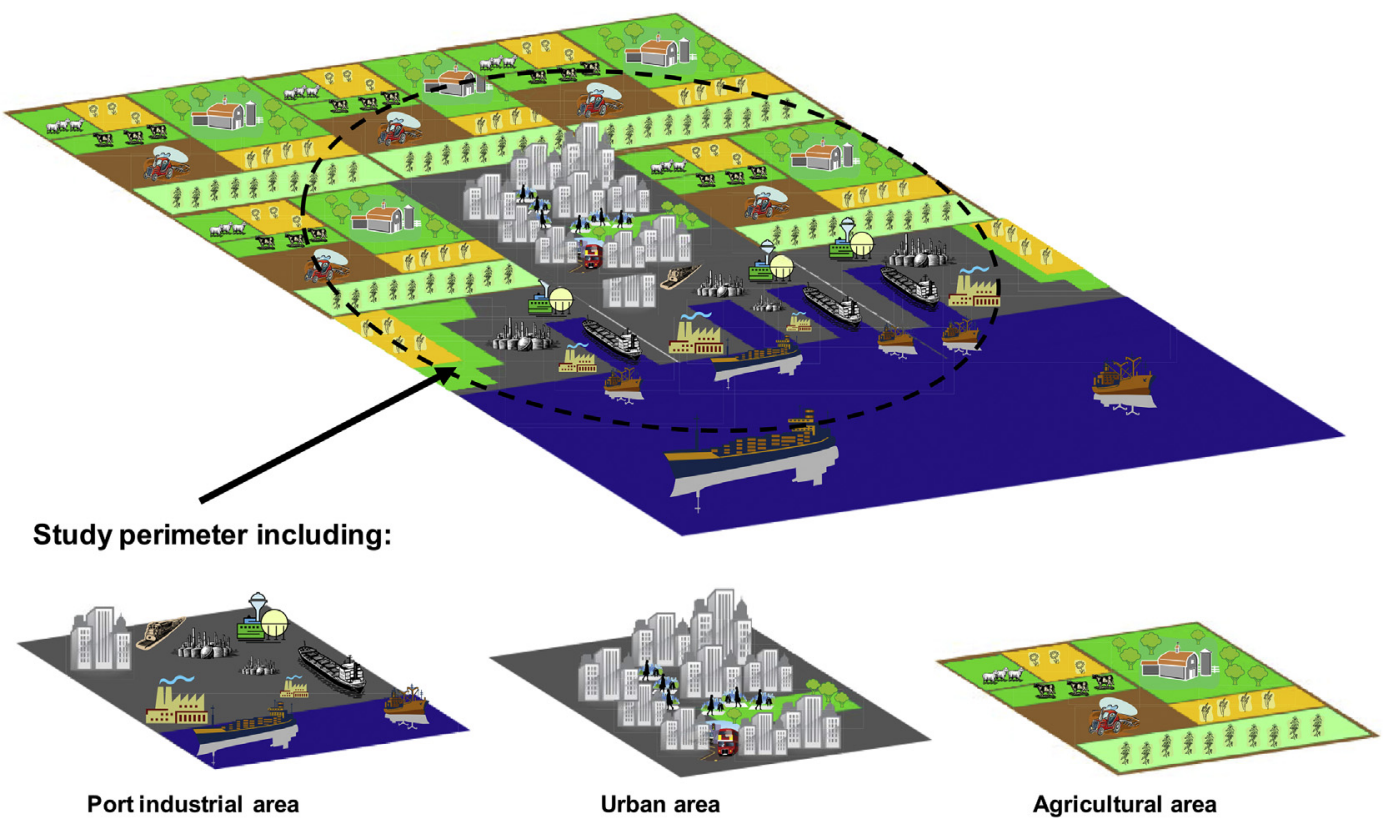

Fig. 1. Case studies perimeter including port industrial area, urban area, and agricultural area.

energy sources. Land use and cover change have also been defined as one of the relevant indicators of interactions between socioeconomic and ecological processes (Redman et al., 2004; Haberl et al., 2006). For Verburg et al. (2009), land change cannot be understood without considering the layer of soil and biomass (land cover), the purposes for which humans exploit the land cover (land use), and the provision of goods and services offered by the land system (land functions). For instance, urbanization has a direct impact on biomass (land cover), terrestrial carbon storage (land functions) and appears as the main driving factor for $\mathrm{CO}_{2}$ emissions through human activities and mobility developed in cities (land uses) (Seto et al., 2012; Wang et al., 2012a,b). They highlight the importance of land function change on the local context. Urban, agricultural, and industrial areas can be considered through the functions they provide to society, based on a wide range of activities. Land use is thus closely interconnected with time use. Time use corresponds to demographic data concerning the structure of activities and employment that are crucial factors influencing land use types and intensity and transformation of land cover (Ohl et al., 2007). Finally, local governance, especially in port regions, which are often influenced by both national and local policies, appears to be a key factor for understanding major socio-ecological trends. It can be defined as the organizations and rules that govern the economic development of a port region and coastal preservation.

To qualify the impact of globalization on the socio-ecological dynamics of a port region, we compared the local changing relations of energy metabolism, land use, time use, and local governance with the total traffic in the port. Our objective is to understand the impact of the trends in a port's overall traffic (in terms of total tonnage and distribution) on local socio-ecological regimes and transitions. It also allows describing the different regimes and transitions steps toward low carbon development. Su et al. (2012) shaped an evaluation index system, among which energy (structure and usage efficiency), time use through economic

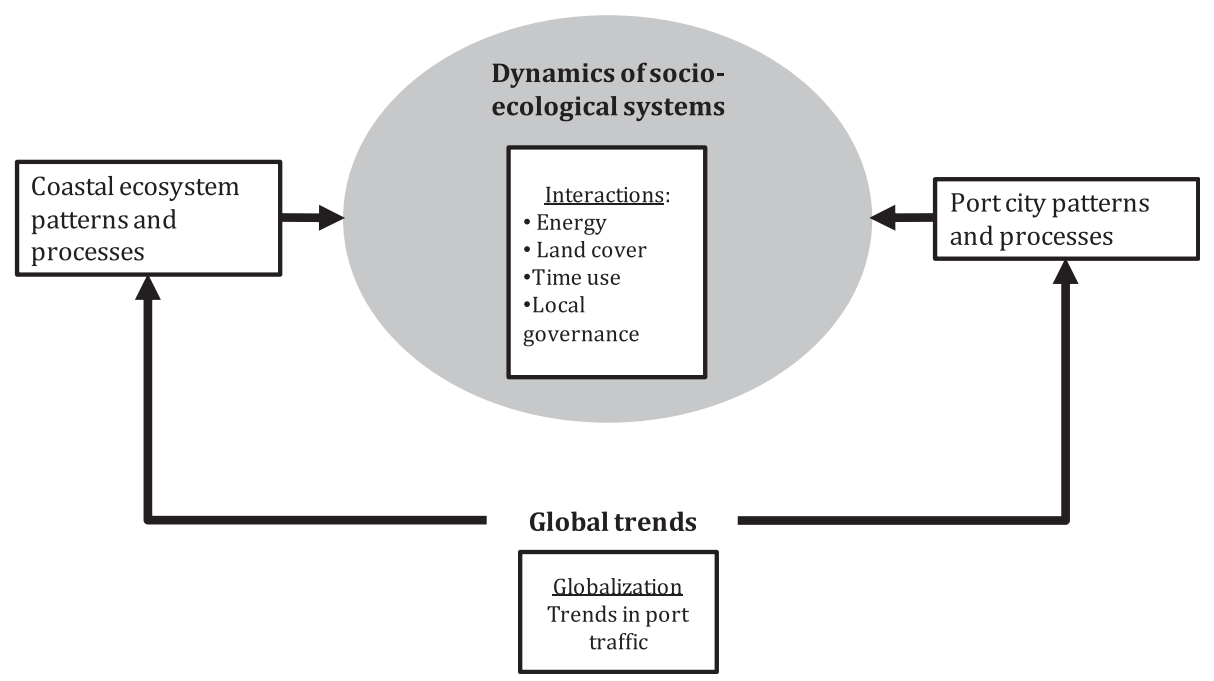

Fig. 2. Characterization of socio-ecological patterns and processes. 
structure and land cover through urbanization appear as relevant criteria to characterize the urban low carbon development level of a city.

\section{Socio-ecological regimes and transitions in port cities in Europe and Asia: analysis of three case studies}

\subsection{Aix-Marseille-Provence metropolitan area (France)}

Table 2 presents the different socio-ecological regimes and transitions in the Aix-Marseille-Provence metropolitan area from the beginning of the 20th century to the present (Fig. 3).

The "primitive port city", characterized by a close spatial and functional association of the old harbor and the city, became increasingly congested (Hoyle, 1989). The need to expand justified the move away from the traditional waterfront, with the development of petrochemical industries around the Etang de Berre (1860-1935). These new port industrial areas were considered as Marseille's spatial overflows or annexes (Borruey, 1998). Strong interactions were maintained between port traffic and trade, industry and city (Georgelin, 1991). In 1900, 70\% of importations were destined for local industries (Roncayolo, 1963). Naval weapons manufacturers, ship repairing activities, and storage and trading companies were owned by a historical network of Marseille families. Local food industries (sugar refinery, oil mills, manufacture of pastas) developed based on the relationships of Marseille with the colonial empire (Garnier and Zimmermann, 2006). Port related industries as well as urban activities were mainly based on a coal based energy system: in $1938,62.8 \%$ of electricity provided by the coal power plant in Gardanne was used by industries, and $28.7 \%$ provisioned residential users (Wolkowitsch, 1991).

During the 1930s, major refineries were built in the Marseille port area. The increasing demands of oil for transport, domestic heating, and electricity production resulted in the exponential growth of local refining capacity, from 3 million tons in 1948 to 14.2 million tons in 1961. While in 1938, crude oil imports hardly reached 1.5 million tons, it exceeded 12 million tons in 1960, and reached 60 million tons in 1970 (Ricard, 1979). The national transition toward a fossil fuel-based energy system, disconnected from local sources of energy, is also reflected at the local scale. While in $1951,58 \%$ of electricity provided by the coal power plant of Gardanne was still used by industries and $28 \%$ provisioned residential users, in 1968, only $33 \%$ of coal based electricity supplied local industries and $3.8 \%$ provisioned residential needs (Wolkowitsch, 1991). The collapse of the colonial empire and the globalization of the economy resulted in a deep transformation of Marseille's spatial and economic configurations. Traditional activities of Marseille port city suffered from national and international competition (Kinsey, 1978; Garnier and Zimmermann, 2006). The surviving factories were absorbed by multinationals companies such as Unilever, Panzani or Beghin Say, and became disconnected from the local context and interests. The port industrial complex in Marseille's old harbor began to decline. With the port reform of 1965, the governance model of Marseille's port changed, from the local operation of the port areas to a management system mainly driven by the national government (Garnier and Zimmermann, 2006). The French government imposed a deep change in local planning, by shattering the traditional regime polarized on Marseille's historical harbor and opening up new peripheral areas for industrial development (Garnier and Zimmermann, 2006). For example, the Fos port-industrial complex, inaugurated in 1968, was meant to stimulate self-sustained growth in the region (Kinsey, 1978). The stagnation of Marseille's historical port-city resulted in a progressive process of disconnection between the city and its peripheral areas (Fellmann and Morel, 1989). At the end of this 


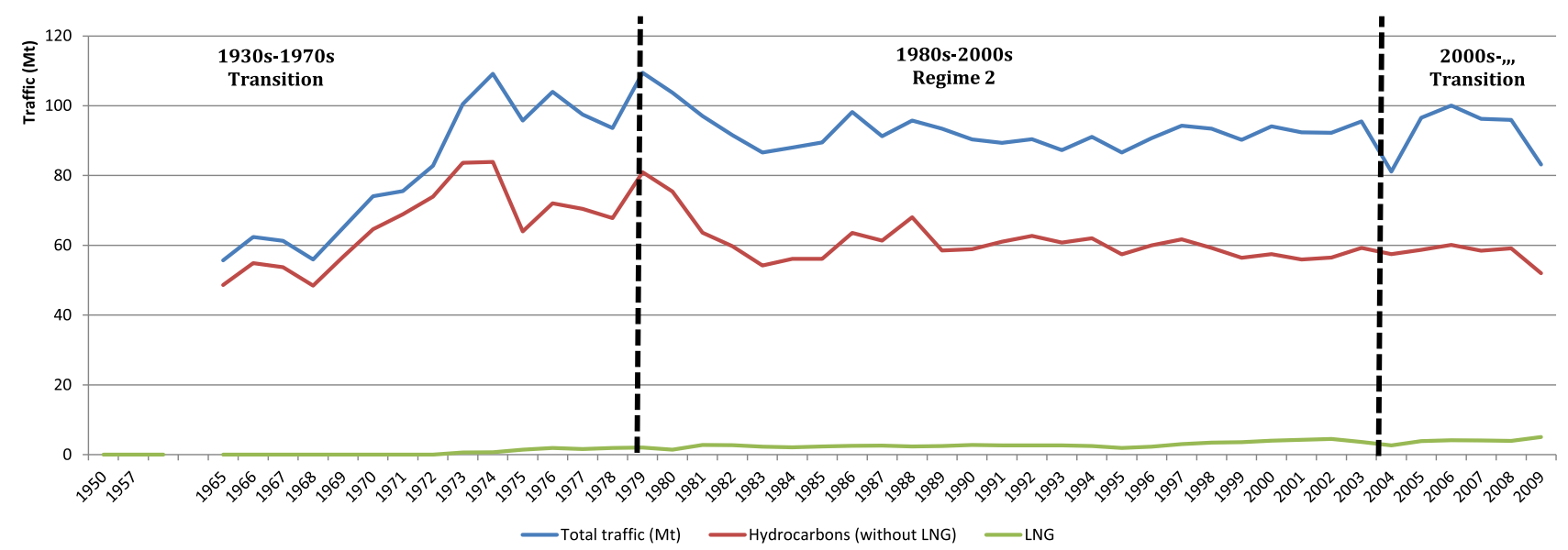

Fig. 3. Total traffic and hydrocarbon traffic in Marseille area.

period of transition, the metropolitan area of Marseille showed two different faces: a modern, dynamic, and highly productive area in the west, and a declining industrial base still surviving in the east (Kinsey, 1978).

In 1970, the main characteristics of a new socio-ecological regime were in place. The Fos port industrial area began its commercialization operations, welcoming industries such as Gaz de France, Air Liquide, Imperial Chemical Industry, and Solmer steelworks (Ricard, 1979). The building of these industrial complexes resulted in the important immigration of temporary construction workers: in 1973-1974, there were 17, 000 workers. The chemical and petrochemical industries provided a growing number of jobs: in 1971, 13,800 people worked in these sectors. There were more than 20,500 in 1975 (Kinsey, 1978). Even if the volume and the productive capacity of Fos were not as high as expected, it became the biggest French port industrial complex, one of the most important in the Mediterranean area (Garnier and Zimmermann, 2006). Port traffic continued to grow exponentially. It nearly doubled from 1965 to 1973 , from 55.7 million tons to 100 million tons. In 1973, $89 \%$ of this overall traffic concerned crude oil and refined importations and exportations (Ricard, 1979). The development of Fos, Lavéra, and Etang de Berre confirmed the multipolarity of Marseille's port area, each pole fostered its own dynamics and autonomy (Garnier and Zimmermann, 2006). The oil shocks did not challenge the local SES: although the global traffic dropped down in 1983, port industrial activities appeared to be robust and adaptable. With the development of major industries in Fos, Lavéra, and Berre, optimization of processes was integrated and flow exchanges developed between companies. For instance, in 1972, Air Liquide started using the frigories released during the regasification of the LNG received by Gaz de France. Inter-industries synergies were also developed between Ugine Acier and Solmer, or Naphtachimie and ICI (Kinsey, 1978). In 1973, a 37\% decrease in the Etang de Berre refinery capacity enabled the refinery to adapt to the new context of supply and demand. In the 1980s, refinery industries started converting their operations by reducing energy consumption, and making a transition toward the production of gasoline and diesel fuel. The diversification of their activities also involved the production of basic inputs for petrochemical industries, resulting in the creation of integrated petrochemical complexes (Wolkowitch, 1991). In 1986, the refining capacity dropped to 26.6 million tons. Port traffic was diversified: the opening of the Fos Tonkin LNG terminal in 1972 allowed LNG traffic to develop, starting with 0.9 million tons in 1973, and exceeding 3 million tons in 1983 (Ricard, 1979). The opening of Fos Cavaou LNG Terminal in 2010 confirmed this trend. The containerization of port traffic can also be analyzed as an adaptation to trends in international trade.

2008 could mark a turning point in Marseille's socio-ecological regime toward a new transition. Some of the early warning signs of such a transition include the loss of 10 million tons of hydrocarbons between 2008 and 2009 in the total traffic, which was considered to be an oil shock locally (Vinzent, 2014). This change could challenge the role of Marseille's port as an importer of fossil fuel energy. In 2011, the closing of the LyondellBasell refinery, which as active in the Etang de Berre area since 1929, was announced. At the same time, the overall trend in the raw material market and the reorganization of the steel industry at an international scale question the future of the steel industry in Fos. A first step toward structural change may be seen in the transition of port management. As the port area had not welcomed new industrial projects since 1989, the port management had to revise its commercialization tactics and develop new strategies including IE, technological mapping, and energy services. Moreover, the new port reform redefined the role of French port authorities. Focusing on issues of local planning, economic development, and multi-modal connections, ports were invited to reconnect with their local context and especially re-build the port-city interface. At the same time, the project of creating an Aix-Marseille-Provence metropolitan area, which had developed since the 1970s, took on a new dimension with the creation in 2012 of an inter-ministerial committee for the definition and development of the metropolitan project. The goal of this project is to go beyond the polycentric spatial and economic organization of the area in order to rebuild territorial coherence at the metropolitan level with local stakeholders. A specific part of this mission deals with the energy transition in the metropolitan area: considering that the metropolitan area only produces $6 \%$ of the energy it consumes, which only includes $2.1 \%$ in renewable energy, the objective is to move toward relative local energy independency by making the most of local sources of energy (MIPPM, 2013). IE is involved in the metropolitan strategy, fostering projects of attractive industrial synergies for new activities and encouraging better port-city nesting through the implementation of energy exchanges between industrial and urban areas. This implies a profound change in the local function of the port and structure, from an importer of energy to and energy producer and operator.

\subsection{Ningbo district (China)}

As presented in Table 3 and Fig. 4, trends in the port city in the Ningbo district can be divided into four distinct periods: from a traditional regime, a transition stepwise process started in 


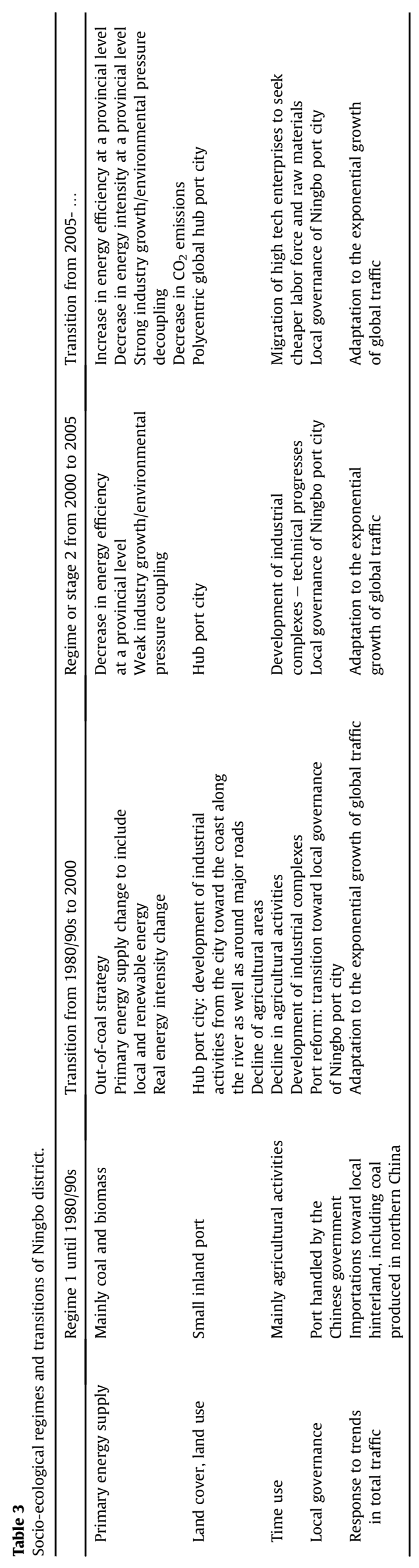

1980-1990, marked by a regime or stage at the beginning of the 21st century.

Before the early 1980s, Ningbo port city was an emblematic "primitive port city" (Hoyle, 1989) with a close spatial and functional connection between the city and the port. For Liu (1995), the international situation and a policy focusing on economic development in the interior area of China explained that the construction of ports did not received high priority. Ningbo port was a small inland port with a cargo throughput of only 40,000 tons in 1949. Zhejiang province was mainly an agricultural area. In 1978, while the population of Ningbo reached 4.57 million inhabitants, $86 \%$ were rural workers, mainly dependent on agriculture and fishing for their livelihoods (Ningbo yearbook, 2013). Historically, the main source of energy in China has been coal, which is used for electric power generation, railway transport, industrial inputs, and heating fuel for the residential and commercial sectors. After the Second World War, China had no foreign exchange and thus had no option but to depend on coal as the main source of energy (Thomson, 2003). Most of the coal was consumed in Manchuria, Shanghai, and in Treaty Ports including Ningbo. In 1936, 22.9\% of coal total consumption was concentrated in the central and eastern regions of China (Thomson, 2003). For Thomson (2003), energy shortages have greatly hindered the industrial, agricultural, and social development of China. The lack of an alternative to coal led to the exploitation of biomass in rural areas, resulting in a loss of thousands of square meters of fertile land.

With the rapid growth of foreign trade, the attention given to port construction was of a much higher priority. It culminated in the opening of China policy in 1978. The construction of ports was regarded as a lever to foster national economic development (Liu, 1995). During the Sixth and Seventh Five-Year Plan (1981-1990), the Chinese government decided to build four international deepwater ports in strategically important economic areas. Among them, Beilun in Ningbo was regarded as a promising area for fostering coastal transportation of mineral and energy products (Wang et al., 2008). In 1984, the Ningbo Economic and Technological Development Zone and the Ningbo Free Trade Zone were created in order to welcome major port industrial activities. In the 1990s, foreign and local investments led to the establishment of a 5 million tons capacity oil refinery and a 300,000 ton capacity ethylene plant, a power plant, a paper mill, a steel plant as well as associated docks and facilities (Wang et al., 2015). In the same period, a 100,000-ton ore berth was built in the harbor (Liu, 1995). The development of port-industrial zones led to an exponential increase in the total traffic. In 1980, the total cargo volume at Ningbo port was around 3 million tons. 233 Ktons of oil products were shipped to Japan, the United States, and Hong Kong. Total cargo traffic reached 25 million tons in 1990: 60\% of Ningbo exported goods were coal, crude oil, and oil products. The main imported goods or raw materials are iron ore from Australia and Brazil (2 Mtons), coal (8 Mtons), crude oil (2 Mtons) and oil products (1.3 Mtons). Ningbo was considered to be the hub for transshipping oil products to other Chinese ports. The development of the Beilun port industrial zone, $40 \mathrm{~km}$ east of Ningbo city, can be seen as a relative port-city spatial disconnection. Nevertheless, Ningbo can be considered as an emblematic hub port city, as defined by Lee et al. (2008), with increasing port productivity concomitant to flow exchanges and organizational interactions with the urban center. In terms of flows exchanges, the port serves the local economic development of Zhejiang province as well as the city of Ningbo (Lo and Song, 1992). Indeed, in the late 1990s, the spatial development of port-related industries, although growing outwardly of the city, were concentrated around local logistic corridors, near the Yangtze River, and around the main roads. In terms of organizational interactions, with the reform of the port 


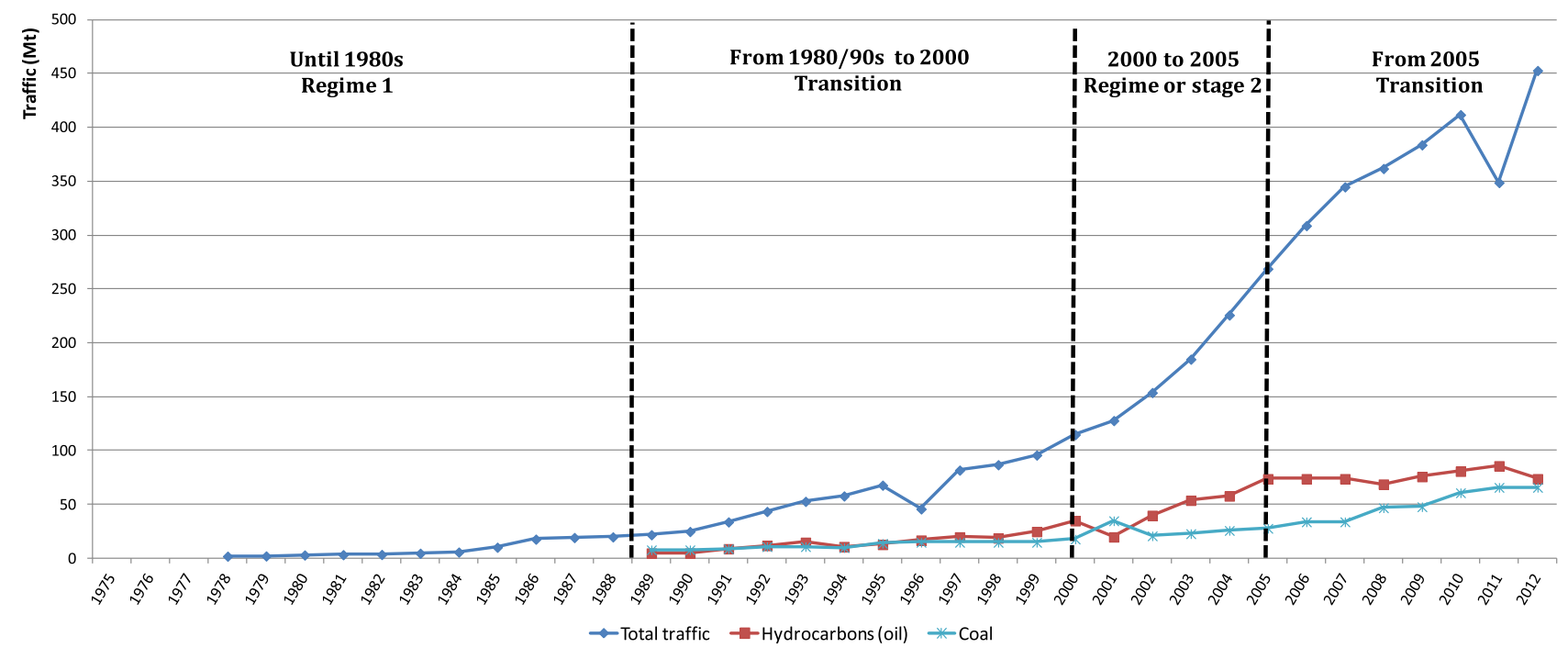

Fig. 4. Total traffic and hydrocarbon traffic in Ningbo district (no data before 1978).

administration system from 1984 to 1988 , the jurisdiction of coastal ports was transferred from the Ministry of Communications to the local authorities. Ningbo port administration was thus transferred to the Ningbo municipality, which was authorized to institute local laws.

The energy industry was a core component of the Sixth FiveYear Plan (1981-1985). The determination to open up China was characterized by a persistent pursuit of foreign capital and technology in order to develop foreign technology, import, and establish joint ventures (Thomson, 2003). Even with the reform and opening up program, the switch toward more modern and efficient fuels has always been deferred. The energy transition required huge investments in new infrastructure and technology that government could not afford (Thomson, 2003). However, the demand for coal began to decline: urban consumption switched to gas for cooking and heating, industries replaced coal with oil or electricity in order to compete internationally. In the mid-1990s, the government gave clear instructions to begin a gradual phasing out of coal (Thomson, 2003). This announced structural change in the primary energy source occurred while the awareness on local and global effects caused by the burning of so much untreated coal could no longer be ignored. The 1990s were also marked by the energy intensity fall in China's industrial sector: $88 \%$ of the cumulative energy saving in the industrial sector from 1990 to 1997 were attributed to real intensity change, with $80 \%$ of such saving from the four energy intensive industries including steel industry and chemicals (Zhang, 2003).

In the 2000s, the transition process seems to reach a step, although the traffic flows still continue to increase. In 2000, the shipping exceeded 110 million tons. In 2012, Ningbo port was considered to be one of the largest international ports, with an annual cargo throughput of 453 million tons, including 66 million tons of coal and 55 million tons of crude oil. The rapid economic development had a high coast in terms of resource and environment. This stage or regime is characterized by weak coupling of industrial growth and environmental pressure. From 2001 to 2005, the Zhejiang energy efficiency decreased and several main environmental pollutant emissions increased significantly. In 2004, Ningbo energy consumption represented nearly 1 million tons of coal per year, and results in a high production of atmospheric pollutants (194 million $\mathrm{m}^{3}$ of waste gas, and up to 20 million tons of $\mathrm{SO}_{2}$ (Ningbo yearbook, 2006). 6 major industries represent $85 \%$ of total consumption of the region of Ningbo (Beilun yearbook, 2013). The high dependence on fossil energy resources, backward technology and outdated equipment finally resulted in technical regress at a national level (Wang et al., 2014).

From 2005, Ningbo port city is in a critical period of transformation toward cleaner energy sources. In Ningbo district, in 2006, a study was conducted to assess the opportunity to covert Zhenhai Power Plant from coal to natural gas power generation. The construction of the East China Sea gas field and the implementation of the LNG terminal also constitute first steps toward this energy transition. The circular economy, promoted in China since the 2000s, also participates in this transition: the main objective is to decrease energy consumption in Ningbo port city. Since 2000, the Ningbo region has aimed to develop looped recycling systems between the 7 major industries, including petrochemical industries, the steel industry, and a paper mill. In 2005, Ningbo Chemical Industrial Zone is listed as a Circular Economy Pilot Park as companies formed a chain of industrial clusters based on the circular economy model (Wang et al., 2008). This period is characterized by the beginning of a strong decoupling between industrial growth and environmental pressure (Wang and Yang, 2015). The east region is leading in terms of energy efficiency, by the active introduction of foreign advanced energy technology, equipment and management experience (Wang et al., 2014). All these initiatives contributed to an increase in energy efficiency and a decrease in energy intensity in the industrial sector of the Zhejiang region (Wang et al., 2012a,b).

\subsection{Ulsan metropolitan area (South Korea)}

A summary of trends in the Ulsan metropolitan area in terms of socio-ecological considerations from pre-1960 to post-2000 is presented in Table 4 and Fig. 5.

Ulsan port was opened with the port opening policy of the Chosun Dynasty in 1426 at the request of the governor of Tsushima, Japan. The population of the Ulsan area grew from slowly 145,904 in 1930 to 206,857 in 1960 (Ulsan metropolitan area, Statistics Korea, 2013). The residents were mainly dependent on agriculture and fishing for their livelihoods. Whale hunting was a famous traditional business. Although, during the colonial period, Ulsan port had expanded and developed for military and trade activities, Ulsan maintained a general fishing port and local market until the 
1950s with no government support to develop the port area. Strong interactions were historically established between port traffic, trade, industry, and the city.

A breakthrough in Korean industry occurred in the 1960s. To strengthen the economy, the Economic Planning Board (EPB) designed a six cycle 5-year economic development plan. Initially, the national government was mainly focusing on coastal areas, which explains why Ulsan was officially granted the status of a city by the national government and selected as a special industrial complex in 1962. The same year, Ulsan port was designated as a trading port in accordance with the first economic plan. Exponential growth in industrial activities took place in the port area, and various major industries were established at that time. SK oil refinery, Korean Fertilizer Company, Hyundai Motor Company, Hyundai Heavy Industry, and S-oil refinery were established in 1962, 1967, 1972, and 1976 respectively. A rapid growth in the amount of marine traffic was observed due to the major industrialization. In 1963, total traffic was hardly 1 million tons, while in 1992, imports and exports to/from Ulsan Metropolitan City totaled $\$ 21$ million. In the 1970s, Onsan and Mipo ports were included in order to meet the increased import/export activities, which led to a polycentric development of industrial and urban activity, disconnecting port industrial activities from the traditional harbor. In 1970, Community Movement started in response to the gap between rural and urban areas. The population of Ulsan increased dramatically from 206,857 in 1960 to 418,326 in 1980 . The industrialization led to an increase in employment in this area. In 1963, there were 948 employees/workers in the manufacturing sector, while it exceeded 74,000 workers by 1989 (Dong-ho Shinn, 1994). To deal with regional disparity, the Korean research institute initiated a ten year (1972-1981) land use plan. In the 1970s, these national level policies were adapted in order to cope with the changing conditions (Dong-ho Shinn, 1994). From 1962 to 1973, there was a structural change in the energy mix: the share of oil in the South Korean energy mix increased from 19\% to 54\%. On the other hand, the share of coal and firewood decreased from $87 \%$ to $42 \%$. From 1970 to 1979 , oil consumption increased from 63 to 163 million barrels. This increase was due to the development of heavy and chemical industries, in which a shift occurred from coal to oil for energy. The two global oil shocks affected the Korean economy negatively, and the country suffered from an acute shortage of energy. To diversify the energy supply and energy sources, the government enacted a "Rational Energy Utilization Act" in 1979. In 1986, oil import sources increased to 21 countries, versus 7 in 1981. Since South Korea has few natural resources, dependence to oil imports raised from $88 \%$ in 1990 to $99 \%$ in 2000 (Park et al., 2008). From the 1980s to the early 2000s, energy consumption increased at a rate of 8.6 per annum versus $4.5 \%$ between 1980 and 1985. The growth of total maritime traffic continued, reaching 21 million tons in 1980, and 123 million tons in 1995.

In the mid-1990s, changes in the Ulsan port city area confirmed these major trends, which stabilized in a regime characterized by a dependency on overseas oil, and the polycentric development of the port industrial area. The Ulsan District consists of two National industrial complexes, Ulsan Mipo National Industrial Complex, and Onsan National Industrial Complex. The development of heavy industry and petrochemical plants in the 1970s created worse environmental conditions in Ulsan. In the 1990s, a waste reduction strategy rather than waste treatment was adopted, and different measures were taken. In 1992, a producer deposit-refund system established a strategy based on incentives for industries to reduce their waste at the source. The "Waste Charge System" introduced in 1993 aimed to reduce waste generation by imposing charges on products that were hard to recycle or that contained hazardous 


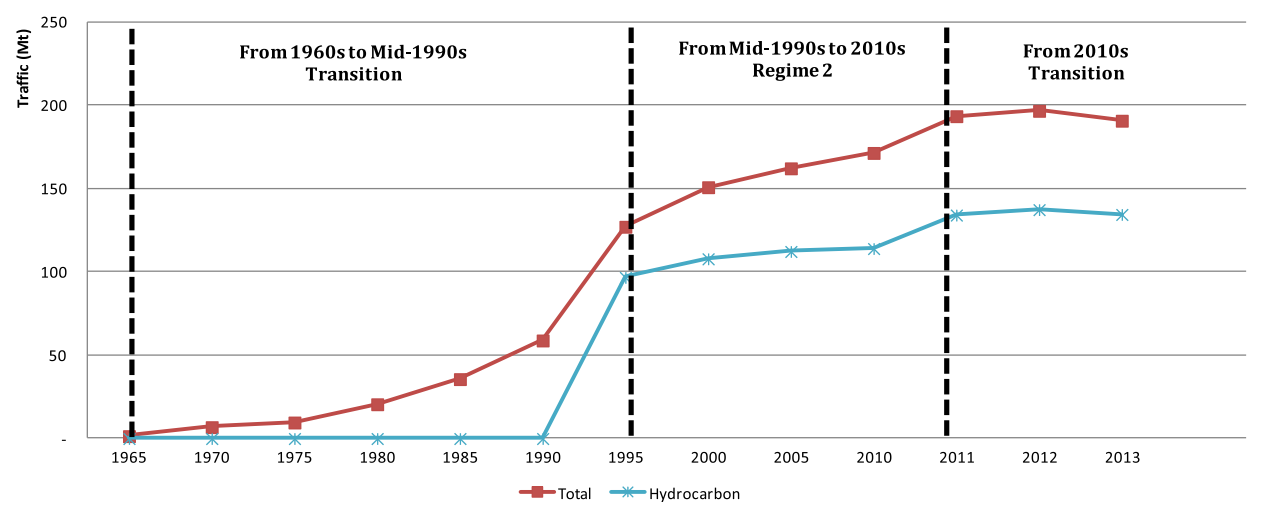

Fig. 5. Total traffic and hydrocarbon traffic in Ulsan.

chemicals. In 1995, the Act to Promote Environmentally Friendly Industrial Structure resulted in the institutional system for cleaner production. An IS network has gradually emerged since the mid1990s (Park et al., 2008). The discharge of pollutants has been partially reduced, and financial resources have been raised by taking these actions. Due to the measures adopted by the city government, environmental conditions in Ulsan have improved considerably since the mid-1990s, as several environmental indicators demonstrate (Kwon Changki, 2003).

This second regime, characterized by growing environmental awareness, prefigured the still on-going transition that followed. A major indicator of this transition concerns energy. Since Korea is mainly dependent on imported fuels for energy production, the government focuses on the efficient use of energy and raw materials. In the case of Ulsan, primary energy consumption in 1998 was 15,180 Ktoe and increased to 24,595 Ktoe in 2011. While primary energy production was 516 and 720 Ktoe in 2004 and 2011 (Year book of regional energy statistics, 2012). Energy production is mainly from liquefied natural gas (LNG) and renewable sources. Different strategies have been employed by the national and regional government in order to use the energy efficiently and move toward low-carbon green energy. In 2000, waste to energy and material recycling based on IE was adapted to achieve ecofriendly development. The Korean government initiated a 15-year eco-industrial park initiative in 2005 (Park and Won, 2007). The Ulsan industrial park was selected as one of the six industrial complexes accepted for this EIP project. The objective is to achieve low-carbon green growth through the efficient use of energy and raw materials (Park, 2011). 27 symbiotic network projects were completed by 2013 , in which $48 \%$ of the IS networks were linked to energy issues (Park, 2013). An investment of \$115.4 million was estimated to result in economic benefits of $\$ 107.9$ million per year. There has been a total reduction of 451,000 tons of $\mathrm{CO}_{2}$ and 4052 tons of air pollution per year thanks to these 27 networks (Park, 2013). The National Low Carbon Green Growth Vision, Ulsan EcoIndustrial Park, and Ulsan Eco-Polis, along with other local and national level strategies are helping to transform the Ulsan metropolitan area into a socio-ecological region where environment, industry, businesses, and human beings can co-exist.

\subsection{Discussion}

\subsubsection{Time frames of trends in port cities and the impact of globalization}

To a certain extent, the trends are similar in the three port cities considered in this study. Their first regime corresponds to that of a "primitive port city" (Hoyle, 1989), which is characterized by a polarization of traditional activities (fishery, agriculture, and portbased traditional activities) and flows toward the historical harbor, mainly based on coal and biomass energy. The end of this historical regime is marked by a profound transition due to the opening of these port cities, de jure or de facto, to global trends such as the growth of international maritime traffic and the beginning of the oil-based globalized economy. The time frame of this major transition depends on the capacity of the port-city system to resist or to adapt to these global changes (Fig. 6). In France, and in Marseille in particular, coal use peaked in the first decades of the 1900s, and the adaptation toward more efficient forms of energy such as oil occurred during the First World War. In Ulsan port city, in South Korea, the industrialization of the 1960s, following the

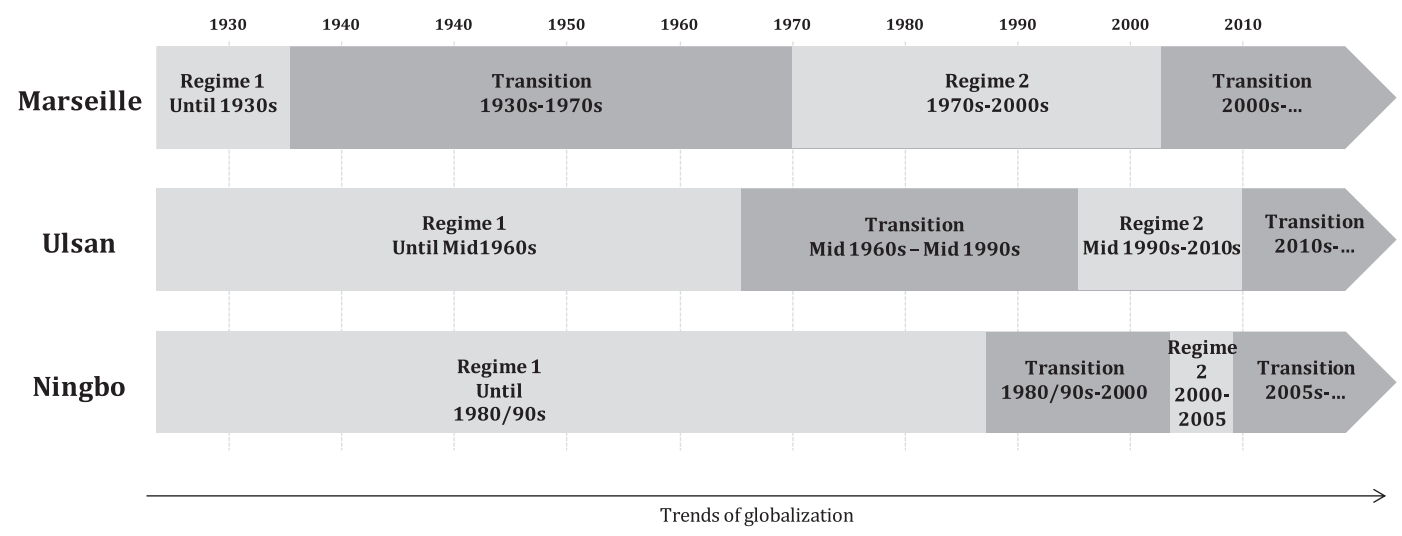

Fig. 6. Comparison of time frames of trends in each port city. 
independence of South Korea at the end of the Second World War, stemmed from the development of major oil refineries. The Chinese transition away from coal occurred in the mid-1990s, as a consequence of the opening up program of 1978 (Thomson, 2003).

These trends are consistent with analysis of Young et al. (2006) on the impact of globalization on socio-ecological systems. Globalization, as an ensemble of interacting changes in socio-ecological systems, induces changes by intensifying and multiplying links and extending activities to the global scale. This first transition is characterized by an exponential growth in total traffic. In Marseille, while the total traffic in 1950 was less than 10 million tons, it exceeded 55 million tons in 1965. In parallel, major port-related companies were absorbed by multinationals. In Ningbo, total traffic was around 25 million tons in 1990, and exceeded 400 million tons in 2010. This increase was accompanied by the development of port industrial zones open to foreign investment needed to build major infrastructure there.

For Marseille and Ulsan, this transitional period was followed by a second regime characterized by the oil-based metabolism of port cities, disconnected from local resources, and a polycentricity that drove away port industrial areas from the historical urban center. Although very dependent on fossil fuel resources, this socioecological regime appeared to be robust and adaptable to the oil shocks of 1973 and 1979. For Anderies et al. (2004), robustness refers to the structural properties of a system that allow it to withstand the influence of disturbances without changing structure and dynamics. In France, this robustness is characterized by a governmental decision to reduce refining capacities as well as reconversion operations to reduce energy consumption. In South Korea, the government enacted the Rational Energy Utilization Act in 1979. The end of this second regime is characterized by the collective awareness of global environmental changes, including global climate change and global resource scarcity.

The fuel-based port city regime is clearly called into question by the global scale at which biophysical changes are taking place. As Young et al. (2006) argue, globalization can pose severe challenges to the resilience and adaptability of socio-ecological systems, as well as to society's capacity to handle the growing vulnerability. For instance, Marseille is now facing the consequences of the global trend in the raw material market, especially oil and steel. The loss in hydrocarbon traffic, closing of refineries, and problems in the steel industry appears to be converging and concomitant signals. Facing a situation in which the robustness of its infrastructure does not seem to be able to maintain the existing socio-ecological system, the Marseille area is starting to become aware of its vulnerability and adapt structurally. In Ulsan, since Korea is mainly dependent on imported fuels for energy production, strategies are also being developed in order to achieve low carbon green growth by efficient use of energy and raw materials. A shared strategy is to move toward energy autonomy by means of a closer connection with local energy sources and better energy use.

The last effect of globalization on port-city socio-ecological trends is the increasing speed of global interactions, processes, and changes. To paraphrase Young et al. (2006), the pace of change is accelerating. For Marseille, which is the first city in our study that went down this pathway, its transition from a "primitive port city" (Hoyle, 1989) to an oil-based port industrial complex disconnected from local energy sources and the local urban center, took more than 40 years. Thirty years later, Ulsan started a similar transition, which lasted only 30 years. Ulsan's second regime also covers a shorter period that makes it difficult to distinguish transition from regime. Ningbo also appears to be a particularly relevant illustration of how time is accelerating. Integrated late into the process of globalization, Ningbo's transition strategy has had to cope simultaneously with all the economic, environmental and societal impacts of globalization because of its opening up to global oilbased economy. Unlike Ulsan and Marseille, Ningbo's second regime appears more like a temporary stage than a stabilized regime, and is juggling with both an out-of-coal transition and a turn toward renewable and local energy. For Young et al. (2006), this increasing speed of response to stressors, threats, and opportunities can enhance resilience and adaptive capacity and reduce vulnerability. It opens up the possibility of moving in a new direction quickly and relatively painlessly.

\subsubsection{Socio-ecological transitions and port-city interactions}

Ports have long been defined as gateways linking a home region to the rest of the world via international transport (Bird, 1983). As nodes in a global transport network, the functions of ports have generally been considered to be exogenous and eccentric to the local context (Bird, 1983). In major European seaports, port functions have been dissociated from city functions. This functional disconnection has resulted in spatial disconnection with the development of huge industrial port complexes, through which the port functions have migrated outside the city, toward peripheral urban areas or greenfield sites (Hoyle, 1989). Marseille is emblematic of trend, with the creation of the Fos port industrial complex in the 1960s (Fig. 7). Thirty years later, for safety reasons, Ningbo seems to be following the same trend in its spatial development with a voluntary and growing disconnection and specialization of the port and the city. However, this trend must be better defined. Lee et al. (2008) describe the various phases in the evolution of Western and Asian port-city interfaces since ancient medieval times. Based on these changes, they contrast two extremes in terms of port-city relationships. On the one hand, a 1/“general port city" model, where the port has been separated from the city and, on the other hand, a 2/"global hub port city" where the port development has been integrated into the urban area. Since the 2000s, Marseille and Ulsan have been involved in a context of metropolization that fosters new forms of cooperation between port and city at a broader scale of decision making and action, questioning in particular the local energy metabolism.

\subsubsection{Innovative regional eco-industrial development trajectories toward low-carbon regimes}

The three case studies considered in this article provide insights into the socio-ecological trajectories of port cities toward lowcarbon regimes. First, adaptation processes toward local and renewable energy do not seem to imply a change in terms of infrastructure, but a change in terms of primary sources of energy. In Marseille, the infrastructure (terminal, plant, pipelines, etc.) of the LNG terminal built by GDF Suez was made adaptable so it would have the capacity to also manage $50 \%$ of biogas coming from the new methanation plant by 2030 . The energy IS network developing in the Ulsan eco-park also aims to replace primary energy sources (oil, LNG) by local energy sources by means of interconnections between existing infrastructure. For instance, the Hankuk paper mill only relies on energy from an industrial symbiosis with LSNikko Corp. for its 150 tons/hour of steam. Similar to ecosystems, this trend is characteristic of a maturation dynamics (Clements, 1916, 1936): in a juvenile stage, fossil energy, such as coal and oil, were used to feed the exponential growth of port-city systems. In a mature stage, fossil energy is being replaced by renewable energy and densification of energy interactions between the system components, in order to maintain the port-city system in a stable state.

This change in primary energy sources presupposes the growing integration and functional complexity of port-city socio-ecological systems. Whereas a fossil based system is mainly supplied by oil or gas fields owned by big companies, the exploitation of local and renewable energy sources relies on the involvement of a 


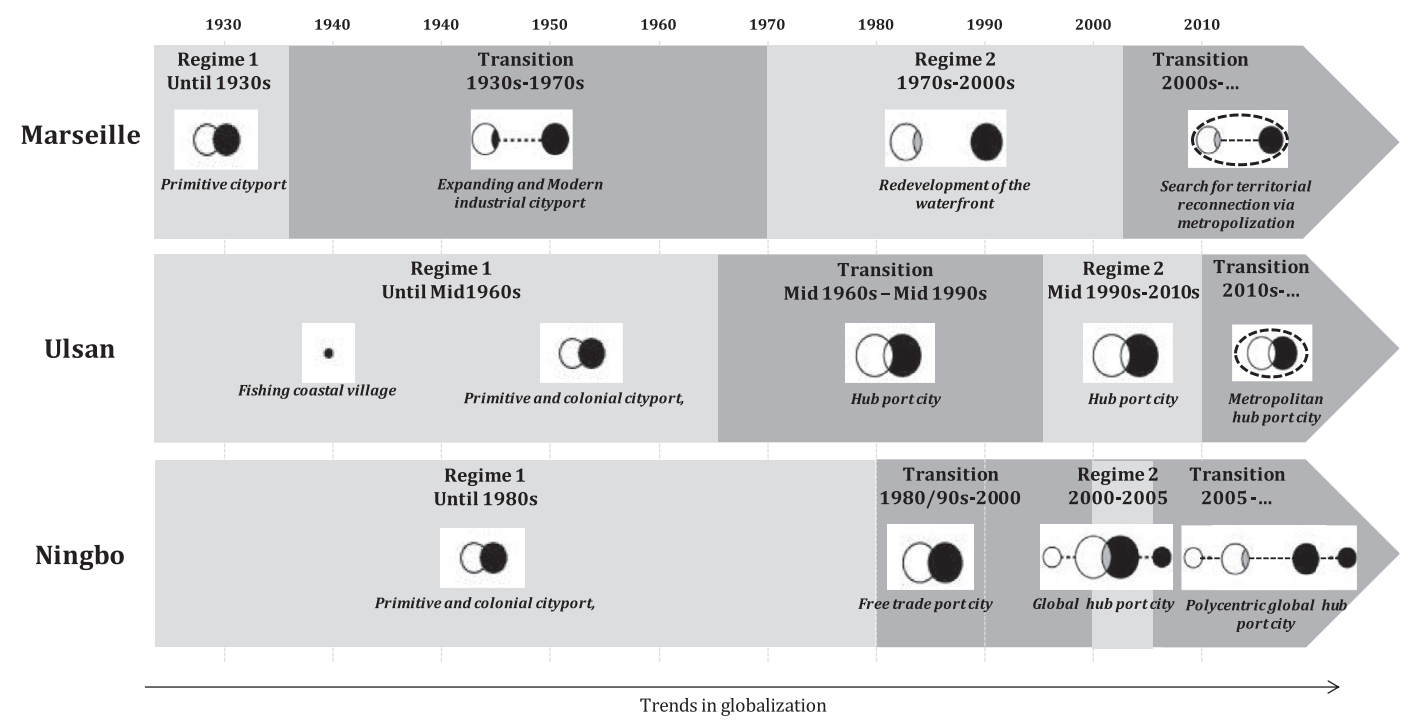

Fig. 7. Port city interactions and trends in globalization (based on and adapted from Lee et al., 2008).

widespread and diversified panel of local stakeholders and activities (industries, agriculture, and urban services). Thus, this trend toward complexity involves growing connectedness between local port-city components: for instance, the eco-industrial chain network in Ningbo Chemical Industry zone forms a symbiotic system based on flow exchanges including basic chemical raw material products, energy, waste water, steam, and hydrogen (Wang et al., 2008). In Ulsan metropolis, 27 industrial symbioses have been identified, 13 of which concern energy issues. This complexity dynamic also implies growing functional diversity in these network components. Flow exchanges occur between companies, such as GDF Suez and Air Liquide in the Marseille port area, or the Ningbo steel industry and Linde Gas through Ningbo's network infrastructure. They also connect port-related companies with urban and agricultural activities. For instance, in Ningbo, the heat network supplied by the Beilun Power plant and Ningbo steel, meets industrial as well as urban and agricultural energy needs. In Ulsan, SK energy provides heat to industries and is planning to supply heat to urban districts. Moreover, local resources such as manure from pig farms and urban sludge, feed a co-digester to produce methane and steam by combustion, in order to supply industries like the Hankuk Paper Company. The study of low carbon transitions thus involves going further the analysis of the sole isolated industrial system by taking into account an open system designed by the interactions occurring between subsystems, such as industrial, agricultural and urban subsystems taken into consideration in our study. In such complex systems, interactions between subsystems are densified and enable the use of new opportunities in an enlarged perimeter. A low carbon optimum is not reached within one process, or one activity. Carbon reductions are performed at the interface between industrial, agricultural and urban activities. For instance, a city can better reach sustainability by considering industrial opportunities of energy optimization (Olazabal, 2012; Chelleri et al., 2012; Geels, 2011) and new cooperation between the local stakeholders (Frantzeskaki, 2013); an industrial area can perform a transition toward low carbon by considering the potential interactions with neighboring agricultural and urban areas.

Bale et al. (2015) described how the theory and tools of complexity science could be used to better understand the complex decision-making processes that are needed to promote a transition to a low-carbon, secure and affordable energy system. To achieve these objectives, a systemic approach like industrial ecology is required to establish a relationship between low-carbon transition, urban sustainability, agricultural and industrial sustainability, in order to describe for each one what are the current model of consumption and production of energy. The characterization of flow metabolism, through MFA for instance (Mat et Gonzalez-Roof, 2012), allows distinguishing the use of net primary energy and final energy by sector (industry, agriculture, residential, etc.) and thus to quantify the economic and structural effect of consumption and production developments and future performance of each sector. Through its systemic approach, industrial ecology enables to consider a complex system that goes further the sole industrial system by considering urban and agricultural subsystems. It allows identifying some relevant synergies between these sectors and to implement new models of development, more collaborative and more complex.

\subsubsection{Efficiency and effectiveness of port city development trajectories toward low carbon development}

Many questions remain and call for further research concerning the socioecological trajectories of port cities toward low carbon development. Among these research issues, one concerns the relative weight of the different socioecological criteria in the succession of the different regimes and transitions: what are the aspects (global traffic trends, energy, land use, time use, etc.) that influence the port city socioecological trajectories? Are these influencing factors similar from an area to another? For instance, Su et al. (2012) characterized the effects of limitation or acceleration of economic, social or energy factors on urban low-carbon development. It would be relevant to study the interactions that occur between these socioecological criteria to enhance the knowledge of the trigger elements toward a socioecological transition. Another aspect to be considered in these interactions between socioecological criteria is the retroaction loops and the impact transfers than can occur within a port city ecosystem or with other areas. Among these retroactions, the rebound effect could provide a relevant highlight on the effectiveness and the time pace of low carbon transition: the direct rebound effect can provide explanations to the offset of the reduction in energy consumption provided by the efficiency improvement (Sorrell and Dimitripoulos, 2008).

For instance, the increase in the share of renewable energy is not necessarily followed by an overall reduction in energy 
consumption, especially of fossil energy. The case of Marseille-Fos appears as a relevant example, as the level of energy consumption in the Etang de Berre area (12.9 Mtep), the main industrial district in the metropolitan area, is well above and even disproportionate in regard to the current local energy production (1.4 Mtep) (MIPPM, 2013). It appears difficult to reach local energy autonomy at a short or even middle term. The objective is thus to enable a gradual convergence of local energy production and local energy demand. However, in order to reduce the overall level of carbon emissions, it will not be enough to reduce energy consumption and to substitute fossil energy supply by renewable sources in the residual energy consumption. It would be appropriate also to better control the processes in order to meet the capacity and time scales of local production. All industrial processes are not affected in the same way by the temporal discontinuity of energy supply, leaving interesting opportunities for using renewable and local energy. A first step consist in the identification of storage capacities and of consumption items that do not require continuous energy inputs as, for instance, heating urban network whose inertia allows to vary supply sources and times. Beyond these first efforts, it would be interesting to better target and distinguish processes that are likely to support power interruptions during energy consumption peaks or low renewable energy production periods for instance. This global management of local activities is at the heart of works on Smart Grids. In Marseille, current experimentations lead to the development of Smart Grids, in order to smooth and match production and consumption periods on the basis of storage techniques such as flywheels, hydraulic storage, methane and $\mathrm{H}_{2}$ production, or heating systems. Their implementation is expected to allow a better articulation of domestic supply networks as well as external supply networks (Moine, 2013).

\section{Conclusion}

This article provides insights on change and adaptation processes toward a low-carbon future in industrial port areas in Asia and in Europe, especially through three case studies (Marseille-Fos in France, Ningbo in China, and Ulsan in South Korea). We conceptualize the historical socio-ecological transition of industrial port cities as a stepwise process of spatial and functional disconnection of port industrial complexes, decoupling the port city metabolism from local resources. We discuss the results of this analysis within the IE framework. The three case studies provide examples of different phases of trends in port industrial systems from the juvenile to the mature phase. The juvenile phase of industrial port areas is characterized by exponential growth in port activity, which leads to a spatial and functional disconnection of port industrial complexes and a strong dependency on exogenous fossil energy. The transition toward a mature phase can be characterized by a slowdown of port exchanges' increase, a diversification of activities, and an intensification of flow exchanges within the port industrial area, and later between the port industrial area and urban and agricultural activities. We highlight the impacts of globalization on port-city socio-ecological trends, highlighting the effects of the integration of port cities in global economic trends, the impact of global awareness on global environmental changes, and the accelerating pace of change. We compare innovative regional eco-industrial strategies, revealing similarities in terms of conversion toward local low carbon sources and growing connectedness and functional diversity of port-industrial systems.

Can we see in these observations the signs of how port cities evolve toward greater resilience? Demographic trends and GDP growth should increase global energy demand in coastal areas and port cities. Energy efficiency policies in cities through building insulation or renewable energy promotion, in industries through technological development and in agriculture through the evolution of farming practices and related fertilization modes, should offset, in part, this upward trend in energy consumption. In terms of production, industrial symbiosis and the intensive use of local low carbon and renewable energy sources, such as biomass, solar, wind or tidal, should increase and reach a larger relative share in the local production/consumption ratio. The increase in complexity, which is an increase in connectedness and diversity, may enhance the resilience of globalized port-city socio-ecological systems. It may also dilute and distribute the impact of strong changes in individual elements upon other elements in the system. On the other hand, an increase in the connectedness of the network can also lead to the destabilization of the system as a whole. An industrial ecosystem is less resistant and less resilient with high inter-firm dependency. In our case studies, industrial symbiosis networks mainly concern petrochemical activities. For instance, the Ulsan SK complex, which includes a refinery and a chemical complex, as well Kumho petrochemical corporation are at the core of the energy symbiosis network. We must not overlook the fact that the dependency of a port-city system on fossil energy still questions its capacity to adapt to a low-carbon future. This socio-ecological approach calls for further investigations in different port cities, in Europe, Asia, and other continents, in order to compare port-city socio-ecological trajectories, confirm the findings reported in this article, and uncover other post-carbon strategies that could enhance resilience in port cities.

\section{Acknowledgments}

The authors would like to thank the various people who helped put us in contact with various resource people via their own networks. The authors are extremely grateful to the Sefacil Foundation for its active support in planning the visit to Asia in 2014. Some of the authors are members of the ELSA research group (Environmental Life Cycle and Sustainability Assessment, http://www.elsalca.org/); they thank all the other members of ELSA for their advice. We are also grateful to Charles La Via for proofreading this article.

\section{References}

Anderies, J.M., Janssen, M.A., Ostrom, E., 2004. A framework to analyze the robustness of socio-"ecological systems from an institutional perspective. Ecol. Soc. 9 (1), 18

Bale, S.E.C., Varga, L., Foxon, T.J., 2015. Energy and complexity: new ways forward. Appl. Energ. 138, 150-159.

Bird, J., 1983. Gateways: slow recognition but irresistible rise. Tijdschr. Econ. Soc Geogr. 74 (3), 196-e202.

Boons, F., Baas, L., 1997. Types of IE: the problem of coordination. J. Clean. Prod. 5 (2), $79-86$.

Borruey, R., 1998. Le port moderne de Marseille, du dock au conteneur (1844-1974) tome IX. Histoire du Commerce et de l'Industrie à Marseille. Chambre de Commerce et d'Industrie Marseille-Provence.

Cerceau, J., Mat, N., Junqua, G., Lin, L., Laforest, V., Gonzalez, C., 2014. Implementing industrial ecology in port cities : international overview of case studies and cross-case analysis. J. Clean. Prod. 74, 1-16.

Chelleri, L., Olazabal, M., Kunath, A., Minucci, G., Waters, J.J., Yumalogava, L., 2012 Multidisciplinary Perspectives on Urban Resilience. Workshop Report, first ed. Basque Centre for Climate Change.

Chen, S.Q., Chen, B., Fath, B.D., 2014. Urban ecosystem modeling and global change: potential for rational urban management and emissions mitigation. Environ. Pollut. 190, 139-149.

Chertow, M.R., 2000. Industrial symbiosis. Literature and taxonomy. Annu. Rev. Energy Environ. 25, 313-337.

Clements, F.E., 1916. Plant Succession, 242. Carnegie Institute Washington Publication, Washington, DC Connell.

Clements, FE. 1936. Nature and structure of the climax. J. Ecol, 24, 252-284.

Ducruet, C., 2009. Port regions and globalization. In: Notteboom, T.E., Ducruet, C., De Langen, P.W. (Eds.), Ports in Proximity: Competition and Coordination Among Adjacent Seaports, Aldershot, Ashgate, pp. 41-53.

Fellmann, T., Morel, B., 1989. Métropolisation et aires métropolitaines: les effets de polarisation sur la métropole marseillaise, mobilité économique, concurrence, complémentarité. Marseilles, EHESS, rapport Plan Urbain, p. 268. 
Feng, Y.Y., et al., 2013. System dynamics modeling for urban energy consumption and $\mathrm{CO}_{2}$ emissions: a case study of Beijing, China. Ecol. Model. 252, 44-52.

Foley, J.A., Defries, R., Asner, G.P., Barford, C., Bonan, G., Carpenter, S.R., Chapin, F.S., Coe, M.T., Daily, G.C., Gibbs, H.K., Helkowski, J.H., Holloway, T., Howard, E.A., Kucharik, C.J., Monfreda, C., Patz, J.A., Prentice, I.C., Ramankutty, N., Snyder, P.K. 2005. Global consequences of land use. Science 309 (5734), 570-574.

Frantzeskaki, N., Wittmayer, J., Loorbach, D., 2013. The role of partnerships in 'realising' urban sustainability in Rotterdam's City Ports Area, The Netherlands. J. Clean. Prod. 65, 406-417.

Garnier, J., Zimmermann, J.-B., 2006. L'Aire Métropolitaine Marseillaise et les territoires de l'industrie. Geogr. Econ. Soc. 2 (8), 215-238.

Geels, F.W., 2011. The multi-level perspective on sustainability transitions: responses to seven criticisms. Environ. Innov. Soc. Transit. 1, 24-40.

Georgelin, J., 1991. Marseille: ville portuaire d'hier à aujourd'hui. Meditéerranée 73, 97-101.

Grimm, N.B., et al., 2008. Global change and the ecology of cities. Science 319 $756-760$.

Haberl, H., Winiwarter, V., Andersson, K., Ayres, R.U., Boone, C., Castillo, A., Cunfer, G., Fischer-Kowalski, M., Freudenburg, W.R., Furman, E., Kaufmann, R. Krausmann, F., Langthaler, E., Lotze-Campen, H., Mirtl, M., Redman, C.L. Reenberg, A., Wardell, A., Warr, B., Zechmeister, H., 2006. From LTER to LTSER: conceptualizing the socioeconomic dimension of long-term socioecological research. Ecol. Soc. 11 (2), 13 [online] URL. http://www.ecologyandsociety.org/ vol11/iss2/art13.

Hoffmann, J., Kumar, S., 2010. Globalization - the maritime nexus. In: Grammenos, C.T. (Ed.), The Handbook of Maritime Economics and Business, second ed. Lloyd's list, pp. 35-64.

Hoyle, B.S., 1989. The port-city interface: trends, problems and examples. Geoforum 20 (4), 429-435.

IPCC, 2014. Climate change 2014: mitigation of climate change. In: Edenhofer, O. Pichs-Madruga, R., Sokona, Y., Farahani, E., Kadner, S., Seyboth, K., Adler, A. Baum, I., Brunner, S., Eickemeier, P., Kriemann, B., Savolainen, J., Schlömer, S. von Stechow, C., Zwickel, T., Minx, J.C. (Eds.), Contribution of Working Group II to the fifth Assessment Report of the Intergovernmental Panel on Climate Change. Cambridge University Press, Cambridge, United Kingdom and New York, NY, USA.

Jung, B.-M., 2011. Economic contribution of ports to the local economies in Korea. Asian J. Shipp. Logist. 21 (1), 1-30.

Kinsey, J., 1978. The application of growth pole theory in the Aire Métropolitain Marseillaise. Geoforum 9, 245-267.

Krausmann, F, Fischer-Kowalski, M., 2013. Global socio-metabolic transition. In: Singh, S.J., Haberl, H., Chertow, M., Mirtl, M., Schmid, M. (Eds.), Long-term Socio-ecological Research. Studies in Society-nature Interactions across Spatia and Temporal Scale. Springer, New York London.

Krausmann, F., Schandl, H., Sieferle, R.P., 2008. Socio-ecological regime transitions in Austria and the United Kingdom. Ecol. Econ. 65, 187-201.

Kwon, Changki, Lee, Sang Hyun, 2003. The experience of industrial relocation in Korean Cities with special reference on Ulsan Metropolitan City. In: Proceedings of Kitakyushu Initiative Seminar on Industrial Relocation.

Lee, S.W., Dong-Woo, S., Ducruet, C., 2008. A tale of Asia's world ports: the spatial evolution in global hub port cities. Geoforum 39, 372-385.

Liu, X., 1995. Integrating the Industrial Complex into the Port: Chinese Developments with Respect to the Metallurgical Sector. Thesis submitted in University of Manitoba. February, 1995.

Lo, Song 1992. China's Coastal Cities, University Hawaii Press, Honolulu.

Mat, N., Gonzalez-Roof, A., 2012. Urban Metabolism of Marseille Provence Metropole. An Overview of Material and Energy Flows on Marseille Provence Metropole through Different Methodologies of Mass and Financial Balance, 1st. Report. Ecotech Sudoe Project.

Merk, O., 2011. The Competitiveness of Global Port-cities: Synthesis Report. OECD URL. http://www.oecd.org/gov/regional-policy/Competitiveness-of-GlobalPort-Cities-Synthesis-Report.pdf.

MIPPM, 2013. La métropole en marche: les chantiers du projet d'Aix-MarseilleProvence. Document de convergence stratégique 2.

Moine, H., Giraud, J., 2013. Ecologie industrielle et transition énergétique au sein du Grand Port Maritime de Marseille. Voyage d'étude AIVP à Marseille. 17 octobre 2013.

Al-Rodhan, Nayef R.F., Stoudmann, G., 2006. Definitions of Globalization: a Comprehensive Overview and a Proposed Definition. Geneva Centre for Security Policy. URL. http://www.gcsp.ch/e/publications/Globalisation/index.htm.

Ningbo and Beilun Statistical Yearbook, 2013, 2011, 2006, 2001, 1996. Available online http://tongji.cnki.net/overseas/engnavi/YearBook.aspx? id $=$ N2011030071\&floor $=1$

OECD, 2009. Sustainable Manufacturing and Eco-innovation. Framework, Practices and Measurement. Synthesis report.
Ohl, C., Krauze, K., Grünbühel, C., 2007. Towards an understanding of long-term ecosystem dynamics by merging socio-economic and environmental research. Criteria for long-term socio-ecological research sites selection. Ecol. Econ. 63, 383-391.

Olazabal, M., Pascual, U., 2012. Postulates of urban resilient sustainability transitions: a cross-disciplinary approach. In: Paper Submitted to ISEE 2012 Conference - Ecological Economics and Rio+20: Challenges and Contributions for a Green Economy. Submission Date: November 22, 2011.

Ostrom, E., 2009. A general framework for analyzing sustainability of socioecological systems. Science 235, 419-422.

Park, H.-S., 2011. Korean Green Innovations through Ulsan EIP Initiative, 7thAsiapacific Eco-business ForumKawasaki, Japan.

Park, H.-S., 2013. Ulsan Ecopolis and Eco-Industrial Parks challenges towards sustainability - a case in progress. In: Presentation in Ecoforum on "Pathway to IEA-T Eco Industrial Town" 12 Dec., Bangkok, Thailand.

Park, H.-S., Won, J.-Y., 2007. Ulsan Eco-industrial Park: challenges and opportunities. J. Ind. Ecol. 11 (3), 11-13.

Park, H.-S., et al., 2008. Strategies for sustainable development of industrial park in Ulsan, South Korea. From spontaneous evolution to systematic expansion of industrial symbiosis. J. Environ. Manag. 87, 1-13.

Redman, C.L., Grove, J.M., Kuby, L.H., 2004. Integrating social science into the longterm ecological research (LTER) network: social dimensions of ecological change and ecological dimensions of social change. Ecosystems 7, 161-171.

Ricard, G., 1979. Marseille-sur-Fos ou la conquête de l'ouest. In: Histoire de l'industrie de Marseille, tome III. Chambre de Commerce et d'Industrie de Marseille.

Roncayolo, M., 1963. Marseille, Notes et Études Documentaires. La Documentation Française.

Schandl, H., Fischer-Kowalski, M., Grunbihel, C., Krausmann, F., 2009. Socio-metabolic transition in developing Asia. Technol. Forecast. Soc. Chang. 76, 267-281.

Seto, K.C. Güneralp, B., Hutyra, L.R. 2012. Global forecasts of urban expansion to 2030 and direct impacts on biodiversity and carbon pools. Proc. Natl. Acad. Sci. 109, 16083-16088.

Shinn, Dong-ho, 1994. The Impact of Industrialization on the Quality of Life in Korea: Case Studies of Ulsan and Kyungju (PhD thesis). The University of British Columbia.

Sorrell, S., Dimitropoulos, J., 2008. The rebound effect: microeconomic definitions, limitations and extensions. Ecol. Econ. 65, 636-649.

Su, M.R., et al., 2012. Low-carbon development patterns: observations of typical Chinese Cities. Energies 5, 291-304.

Thomson, E., 2003. The Chinese Coal Industry: an Economic History. RoutledgeCurzon, United Kingdom, London.

Ulsan Metropolis, Statistics Korea, 2013. Available online: http://english.ulsan.go.kr/ common/Index.do? $m e$ thod=init\&func $=$ select\&PGM_GBN=index

UNCTAD, 2011. Review of Maritime Transport. United Nations, New York and Geneva. URL. http://unctad.org/en/docs/rmt2011_en.pdf.

Vallega, A., 2001. Urban waterfront facing integrated coastal management. Ocean Coast. Manag. 44, 379-410.

Verburg, P.H., van de Steeg, J., Veldkamp, A., Willemen, L., 2009. From land cover change to land function dynamics: a major challenge to improve land characterization. J. Environ. Manag. 90, 1327-1335.

Vinzent, J., 2014. Un choc pétrolier affecte le port de Marseille-Fos. Marsactu.

Wang, Z., Yang, L., 2015. Delinking indicators on regional industry development and carbon emissions: Beijing-Tianjin-Hebei economic band case. Ecol. Indic. 48, pp41-48.

Wang, et al., 2008. Framework of Eco-industrial Park development based on circular economy: a case study of Ningbo Chemical Industry Zone. Sci. Geogr. Sin. 28 (5), 624-630.

Wang, Z., Yin, F., Zhang, Y., Zhang, X., 2012a. An empirical research on the influencing factors of regional $\mathrm{CO}_{2}$ emission: evidence from Beijing City, China. Appl. Energ. 107, 451-463.

Wang, Z., Zeng, H., Wei, Y., Zhang, Y., 2012b. Regional total factor energy efficiency: an empirical analysis of industrial sector in China. Appl. Energ. 97, 115-123.

Wang, Z., Wang, C., Yin, J., 2015. Strategies for addressing climate change on the industrial level: affecting factors to $\mathrm{CO} 2$ emissions of energy intensive industries in China. Nat. Hazards 75, 303-317.

Wang, Z., Feng, C., Zhang, B., 2014. An empirical analysis of China's energy efficiency from both static and dynamic perspectives. Energy 74, 322-330.

Wolkowitsch, M., 1991. Les industries de l'aire métropolitaine marseillaise en 1989 et leur avenir. Mediterranée 73, 21-38.

Young, O.R., Berkhout, F., Gallopin, G.C., Janssen, M.A., Ostrom, E., van der Leeuw, S., 2006. The globalization of socio-ecological systems an agenda for scientific research. Glob. Environ. Chang. 16, 304-316.

Zhang, Z.X., 2003. Why did the energy intensity fall in China's industrial sector in the 1990s? The relative importance of structural change and intensity change. Energ. Econ. 25, 625-638. 